\title{
ALLOZYME DIVERGENCE WITHIN THE CANIDAE
}

\author{
ROBERT K. WAYNE ${ }^{1}$ AND STEPHEN J. O'BRIEN \\ Laboratory of Viral Carcinogenesis, Section of Genetics, \\ National Cancer Institute, Frederick, Maryland 21701
}

\begin{abstract}
Protein products of 51 genetic loci were analyzed by gel electrophoresis using extracts of blood and tissue culture specimens from 12 of the 14 extant canid genera. Genetic distances were calculated and used to derive phenetic trees. The results suggest that the Canidae can be divided into several distinct groups. The wolf-like canids are a group that includes species in the genus Canis and Lycaon pictus (African wild dog). Speothos venaticus (Brazilian bush dog) is weakly associated with this group. Based on the calibration of a consensus tree with a fossil date, Canis mesomelas (black-backed jackal) and Speothos venaticus separated first, approximately 6 million years before present (MYBP). Lycaon pictus and C. latrans (coyote) separated from the line leading to C. lupus (grey wolf) and C. familiaris (domestic dog) approximately 3 MYBP. These results suggest that the blade-like trenchant heel on the carnassial tooth has evolved independently at least twice within the Canidae.

Several distinct genetic stocks appear to have led to the extant South American canids. Chrysocyon brachyurus (maned wolf) is estimated to have diverged from Dusicyon vetulus (hoary fox) and Cerdocyon thous (crab-eating fox) approximately 6 MYBP. The divergence time of the last two genera is fairly recent (2-3 MYBP) and is coincident with the opening of the Panamanian land bridge. The remaining South American canid included in this survey, Speothos venaticus, is clustered with the wolf-like canids. The Vulpes-like canids are a distinct phenetic group that includes species in the genera Vulpes, Alopex and Fennecus. Their estimated time of divergence from all the other canids, approximately 9 MYBP, is among the oldest within the Canidae. Among the Vulpes-like canids we surveyed, Alopex lagopus (arctic fox) and Vulpes macrotis (kit fox) appear genetically most closely related. Finally, the biochemical data support the generic status of three canid genera: Urocyon, Nyctereutes, and Otocyon. These taxa are not closely related to any of the surveyed canid species. [Allozyme; electrophoresis; phenogram; Canidae; evolution; trenchant heel; South America.]
\end{abstract}

The Canidae is a morphologically diverse family of dog-like carnivores that, according to Stains (1975), includes 14 extant genera and 34 species (excluding Dasycyon hagenbecki, which is known from only one museum study skin). Classifications of the family have often conflicted, probably because of morphologic convergences (Huxley, 1880; Simpson, 1945; Langguth, 1969, 1975; Clutton-Brock et al., 1976; Van Gelder, 1978). In this study, we use a genetic approach, gel electrophoresis of soluble blood proteins, to analyze relationships of canids. Except for the rare Asiatic dhole, Cuon alpinus, and the possibly extinct Atelocynus microtis (short-eared dog), all genera of extant canids are represented in our sample.

Phenetic trees based on differences in

\footnotetext{
${ }^{1}$ Present address: Department of Biology, University of California at Los Angeles, Los Angeles, California 90024 .
}

gene frequencies may suggest instances of apparent rapid morphologic evolution and evolutionary parallelism (cf. Larson, 1984; Shaffer, 1984; Wake and Yanev, 1986). A potential instance of evolutionary parallelism among canids is the evolution of a trenchant or blade-like heel on the carnassial or meat-slicing teeth $\left(\mathrm{M}_{1} \mathrm{P}^{4}\right)$ of carnivores. In most canids, the carnassial tooth has a bladed anterior portion and a posterior semi-circular basin. In canids with a trenchant heel, the basin is reduced and altered to form a second blade. Presumably, this increases the functional length of the carnassial blade and hence the ability to slice meat (Ewer, 1973; Van Valkenburgh, in press). Canids with this type of dentition are also characterized by a reduction of the post-carnassial molars whose function is primarily to grind bone and coarse plant foods. The presence of the trenchant heel in three canid species, Speothos venaticus (Brazilian bush dog); Lycaon 
pictus (African wild dog), and Cuon alpinus (Asiatic dhole) led Simpson (1945) and Stains (1975) to unite them in a single subfamily, the Simoncyoninae. However, the latter two taxa are wolf-like in external body form and quantitative measurements of the cranial and appendicular skeleton and chromosome morphology tend to align Lycaon and Cuon with the wolf-like canids of the genus Canis (Chiarelli, 1975; CluttonBrock et al., 1976; Dutrillaux, 1986; Wayne, 1986a, b; Wayne et al., 1987a). Moreover, Lycaon and Cuon appear to be ecological surrogates of the Holarctic species, Canis lupus (grey wolf), in Africa and Asia, respectively. Like the wolf, they are highly social hunters of large game (Nowak and Paradiso, 1983). In contrast, the South American trenchant heel dog, Speothos venaticus is small $(<10 \mathrm{~kg})$ and is proportioned more like a relatively slow, ambush hunter than a gracile wolf (Van Valkenburgh, 1985, 1987). Thus, the trenchant heel may have evolved in parallel in the two wolf-like canids and in Speothos venaticus. To test this idea, we analyze proteins from two genera of trenchant heel dogs: Speothos and Lycaon. Specimens of Cuon are extremely rare and were not available for analysis.

A second question concerns the rate and direction of morphologic evolution. A major evolutionary experiment was initiated by the closing of the Panamanian isthmus 2-3 million years ago (Marshall et al., 1982). Prior to this time, there were no placental terrestrial carnivores in South America. Into this largely depauperate carnivore fauna, ancestors of the recent South American canids entered and diversified. The result is an entirely endemic canid fauna of 10 recent species that are placed into 36 genera (Langguth, 1969, 1975; CluttonBrock et al., 1976; Van Gelder, 1978). Relative to other canids, several species are morphologically atypical. For example, Speothos has a carnivorous dental formula combined with a short-legged and elongate body form. In contrast, Chrysocyon brachyurus, the maned wolf, or "fox-onstilts", is extremely long-legged, a feature which presumably represents an adapta- tion to the long grass of the South American plains (Langguth, 1975). Most of the other South American canids can be described as fox-like, but vary considerably in size and morphology (Langguth, 1969). Forms directly ancestral to these diverse South American taxa are not known from the North American fossil record (Berta, 1979, 1984; Kurten and Anderson, 1980). Thus, a crucial question concerns whether such morphologic extremes could have evolved rapidly from a single ancestor that entered South America during the early Pliocene or whether several ancestral stocks gave rise to the extant South American species. In this study, the genetic relationship between two of the most unusual taxa, Speothos and Chrysocyon, as well as species from two other genera, Cerdocyon and Dusicyon are analyzed to determine if they form a closely-related and possibly monophyletic group.

Finally, relationships of canids based on our data are compared with those derived from morphologic and karyologic approaches (Langguth, 1969, 1975; CluttonBrock et al., 1976; Van Gelder, 1978; Wurster-Hill and Centerwall, 1982; Berta, 1984; Wayne et al., 1987a, b). We compare available data from the fossil record with the branching patterns and divergence times indicated by the biochemical data.

\section{MATERIALS AND METHODS}

Products of 51 presumptive genetic loci were examined in 17 canid species (see Table 1 and Appendix 1), each represented by a single individual. Not all loci were scored in every species (see Appendices 1 and 2). With most species, larger sample sizes are extremely difficult to obtain due to the rarity of the species. The use of such a small sample size appears acceptable if the number of loci is sufficiently large $(>30)$, the genetic distances between taxa are large ( $>0.17)$, and heterozygosity is low $(<0.10)$ (Sarich, 1977; Nei, 1978; Gorman and Renzi, 1979; Nei et al., 1983). Because genetic distances between the canid genera were fairly large (Tables 2,3 ) and the genic heterozygosity of the canids that have 
been surveyed is generally low (Fisher et al., 1976; Simonsen, 1976) the use of a single individual to represent each species is justifiable.

Fifteen to $20 \mathrm{cc}$ of whole blood in heparin were obtained from each of the canids listed in Table 1. Blood was then separated by centrifugation into components containing plasma, erythrocytes and leukocytes. The clear plasma and an aliquot of $1-2$ cc of blood from the bottom of the tube are removed (leaving the interface with white blood cells intact). The red cell aliquot is washed two times in buffered saline. The remaining blood is lysed with two volumes ACK lysing buffer for approximately 10 minutes, pelleted and washed in buffered saline. Red and white cells are prepared for electrophoresis by sonication and three cycles of freeze-thawing to release soluble blood proteins into the supernatant. After centrifugation, the supernatant was stored at $-70^{\circ} \mathrm{C}$. We obtained skin biopsies of most of the canids and used these to establish primary fibroblast cultures (see Table 1). Fibroblast cultures from canids grew slowly so fibroblast lines were transformed with a feline retrovirus to obtain rapid cell proliferation (Wayne et al., 1987a). Tissue obtained from these transformed cell lines was prepared for electrophoresis by washing twice in buffered saline followed by three freezethaw cycles as outlined above.

Electrophoresis of the 51 protein products was performed according to the conditions given in Appendix 1. Depending on the tissue specificity of each enzyme and the availability of samples, each locus was assayed in as many tissues as possible (Table 1, Appendix 1). Allozyme polymorphisms can be more confidently scored using this approach because their presence can be corroborated in different tissues. Allozyme polymorphisms were given alphabetical designations with the most common allele labeled $A$.

Tissues from the 17 canid species were divided into two samples that were analyzed separately. Species in the first sample represent a family-wide survey and include 11 species from 10 canid genera (Ta- ble 1). Ursus arctos (brown bear), the outgroup, is included as a twelfth species. Species in the second sample were intended to resolve relationships among more closely related taxa and include 11 species from two distinct groups: 1) the wolf-like canids, including five species and a South American canid as an outgroup; and 2) the Vulpes-like canids including five species (Table 1). Allozyme polymorphisms were scored and given letter designations separately in the family-wide and generic level surveys (Appendix 2). Alleles are not necessarily homologous between the two surveys and genetic distances were computed separately for samples 1 and 2 .

We used the BIOSYS-1 program of Swofford and Selander (1981) to calculate Nei's (1978), Rogers' (1972) and Cavalli-Sforza and Edwards' (1967) chord distances. BIOSYS-1 was then used to generate separate UPGMA and distance-Wagner trees of species in samples 1 and 2 (Table 1 ). The topology of trees that were derived from these distance measures is similar. We present Nei's (1978) distance only. We chose a UPGMA tree based on Nei's genetic distance modified for small sample size and a distance-Wagner tree based on Cavalli-Sforza and Edwards' chord distance (Cavalli-Sforza and Edwards, 1967; Nei, 1978) because of simulations done by Nei et al. (1983). Their results suggest that 1) UPGMA and distance-Wagner trees generated with Cavalli-Sforza and Edwards' (1967) chord distance produce the most accurate branching patterns; and 2) Nei's distance (1978) gave the best estimate of branch lengths when used to generate a UPGMA tree. However, the Nei et al. (1983) results must be interpreted with caution because considerable controversy surrounds the use of distance data to estimate topologies and branch lengths (Farris, 1981, 1985, 1986; Felsenstein, 1984, 1986). The distance-Wagner tree was optimized to allow for negative branch lengths, which facilitates comparison of this tree to the UPGMA tree with the goodness-of-fit measures (Swofford, 1981; Hedges, 1986). Distance-Wagner trees for sample 1 and for the wolf-like canids were rooted using $U r$ - 
TABLE 1. Group membership, scientific and common names, geographic range, source of tissues and tissue types of the canids analyzed in this study. Geographic range data from Nowak and Paradiso (1983). Source: CMZ, Catoctin Mountain Zoo, Frederick, Maryland; DZP, Denver Zoological Park, Denver, Colorado; JBZ, Johannesburg Zoo, Johannesburg, South Africa; NIHP, National Institute of Heath Animal Facility, Poolsville, Maryland; NZP, National Zoological Park, Washington, D.C.; PPZ, Potter Park Zoo, Lansing, Michigan; RDZ, Rio de Janeiro Zoo, Rio de Janeiro, Brazil; SAZ, San Antonio Zoological Garden, San Antonio, Texas; SDZ, San Diego Zoological Park, San Diego, California. Tissue: $R=$ red blood cells, $L=$ lymphocytes, $C=$ transformed cultured cells.

\begin{tabular}{|c|c|c|c|c|}
\hline Species (code) & Common name & Geographic range & Source & Tissue \\
\hline \multicolumn{5}{|l|}{ Sample 1} \\
\hline $\begin{array}{l}\text { Ursus arctos (Uar) } \\
\text { Canis familiaris (Cfa) } \\
\text { C. lupus (Clu) } \\
\text { Speothos venaticus (Sve) } \\
\text { Chrysocyon brachyurus (Cbr) } \\
\text { Dusicyon vetulus (Dve) } \\
\text { Cerdocyon thous (Cth) } \\
\text { Urocyon cinereoargenteus (Uci) } \\
\text { Octocyon megalotis (Ome) } \\
\text { Vulpes vulpes (Vvu) } \\
\text { Fennecus zerda (Fze) } \\
\text { Nyctereutes procyonoides (Npr) }\end{array}$ & $\begin{array}{l}\text { Brown bear } \\
\text { Domestic dog } \\
\text { Grey wolf } \\
\text { Bush dog } \\
\text { Maned wolf } \\
\text { Hoary fox } \\
\text { Crab-eating fox } \\
\text { Grey fox } \\
\text { Bat-eared fox } \\
\text { Red fox } \\
\text { Fennec } \\
\text { Raccoon dog }\end{array}$ & $\begin{array}{l}\text { Holarctica } \\
\text { World wide } \\
\text { Holarctic } \\
\text { South America } \\
\text { South America } \\
\text { South America } \\
\text { South America } \\
\text { North America } \\
\text { Africa } \\
\text { Holarctic } \\
\text { North Africa } \\
\text { Asia, Europe }\end{array}$ & $\begin{array}{l}\text { NZP } \\
\text { NIHP } \\
\text { SDZ } \\
\text { NZP } \\
\text { NZP } \\
\text { RDZ } \\
\text { PPZ } \\
\text { CMZ } \\
\text { NZP } \\
\text { CMZ } \\
\text { SAZ } \\
\text { DZP }\end{array}$ & $\begin{array}{l}\text { R, L, C } \\
\text { R, L, C } \\
\text { R, L, C } \\
\text { R, L, C } \\
\text { R, L, C } \\
\text { R, L, C } \\
\text { R, L, C } \\
\text { R, L, C } \\
\text { R, L, C } \\
R, L, C \\
R, L, C \\
R, L, C\end{array}$ \\
\hline \multicolumn{5}{|l|}{ Sample 2} \\
\hline $\begin{array}{l}\text { Wolf-like canids } \\
\text { Canis familiaris (Cfa) } \\
\text { C. lupus (Clu) } \\
\text { C. latrans (Cla) } \\
\text { Lycaon pictus (Lpi) } \\
\text { C. mesomelas (Cme) }\end{array}$ & $\begin{array}{l}\text { Domestic dog } \\
\text { Grey wolf } \\
\text { Coyote } \\
\text { African wild dog } \\
\text { Black-backed jackal }\end{array}$ & $\begin{array}{l}\text { World wide } \\
\text { Holarctica } \\
\text { North America } \\
\text { Africa } \\
\text { Africa }\end{array}$ & $\begin{array}{l}\text { NIHP } \\
\text { SDZ } \\
\text { CMZ } \\
\text { SDZ } \\
\text { JBZ }\end{array}$ & $\begin{array}{l}R, L, C \\
R, L, C \\
R, L \\
R, L, C \\
R, L\end{array}$ \\
\hline $\begin{array}{l}\text { South American canid } \\
\text { Chrysocyon brachyurus (Cbr) }\end{array}$ & Maned wolf & South America & NZP & $R, L, C$ \\
\hline $\begin{array}{l}\text { Vulpes-like canids } \\
\text { Fennecus zerda (Fze) } \\
\text { Vulpes chama (Vch) } \\
\text { V. vulpes (Vvu) } \\
\text { Alopex lagopus (Ala) } \\
\text { V. macrotis (Vma) }\end{array}$ & $\begin{array}{l}\text { Fennec } \\
\text { Cape fox } \\
\text { Red fox } \\
\text { Arctic fox } \\
\text { Kit fox }\end{array}$ & $\begin{array}{l}\text { North Africa } \\
\text { South Africa } \\
\text { Holarctica } \\
\text { Holarctica } \\
\text { Western U.S. }\end{array}$ & $\begin{array}{l}\text { SAZ } \\
\text { JBZ } \\
\text { CMZ } \\
\text { CMZ } \\
\text { NZP }\end{array}$ & $\begin{array}{l}R, L, C \\
R, L \\
R, L, C \\
R, L, C \\
R, L, C\end{array}$ \\
\hline
\end{tabular}

sus arctos and Chrysocyon brachyurus, respectively, as outgroups. The tree for the Vulpes-like canids was rooted at the midpoint. Two goodness-of-fit measures are presented here: Prager and Wilson's F-statistic (1976) and the cophenetic correlation coefficient (Sneath and Sokal, 1973; Nei, 1977). Finally, we used the CONTREE subroutine contained in the PAUP program by David L. Swofford (Version 2.4) to calculate the topology of a consensus tree from UPGMA and distance-Wagner trees of each group using the "strict" method outlined by Rohlf (1982).

\section{RESULTS}

\section{Sample 1}

Genetic distance values range from 1.387 (Ursus arctos/Urocyon cinereoargenteus) to
0.042 (Canis lupus/C. familiaris) (Table 2). Forty loci $(78 \%)$ are polymorphic among the canids in sample 1 . The outgroup Ursus arctos is genetically distant from all canids, the average distance is $1.16 \pm 0.10$ and the outlying values are 0.999 (Chrysocyon/Ursus) and 1.387 (Urocyon/Ursus). This suggests both an ancient divergence of this species from extant canids and, because of a relatively narrow range of values, a uniformity in the rate of protein evolution in the different canid lineages. The average distance value between canids is 0.33 . The most closely related pairs are: Canis familiaris (domestic dog) and Canis lupus (grey wolf), 0.042; Cerdocyon thous (crab-eating fox) and Dusicyon vetulus (hoary fox), 0.101 ; and Fennecus zerda (fennec) and Vulpes vulpes (red fox), 0.131. Generally, the larg- 


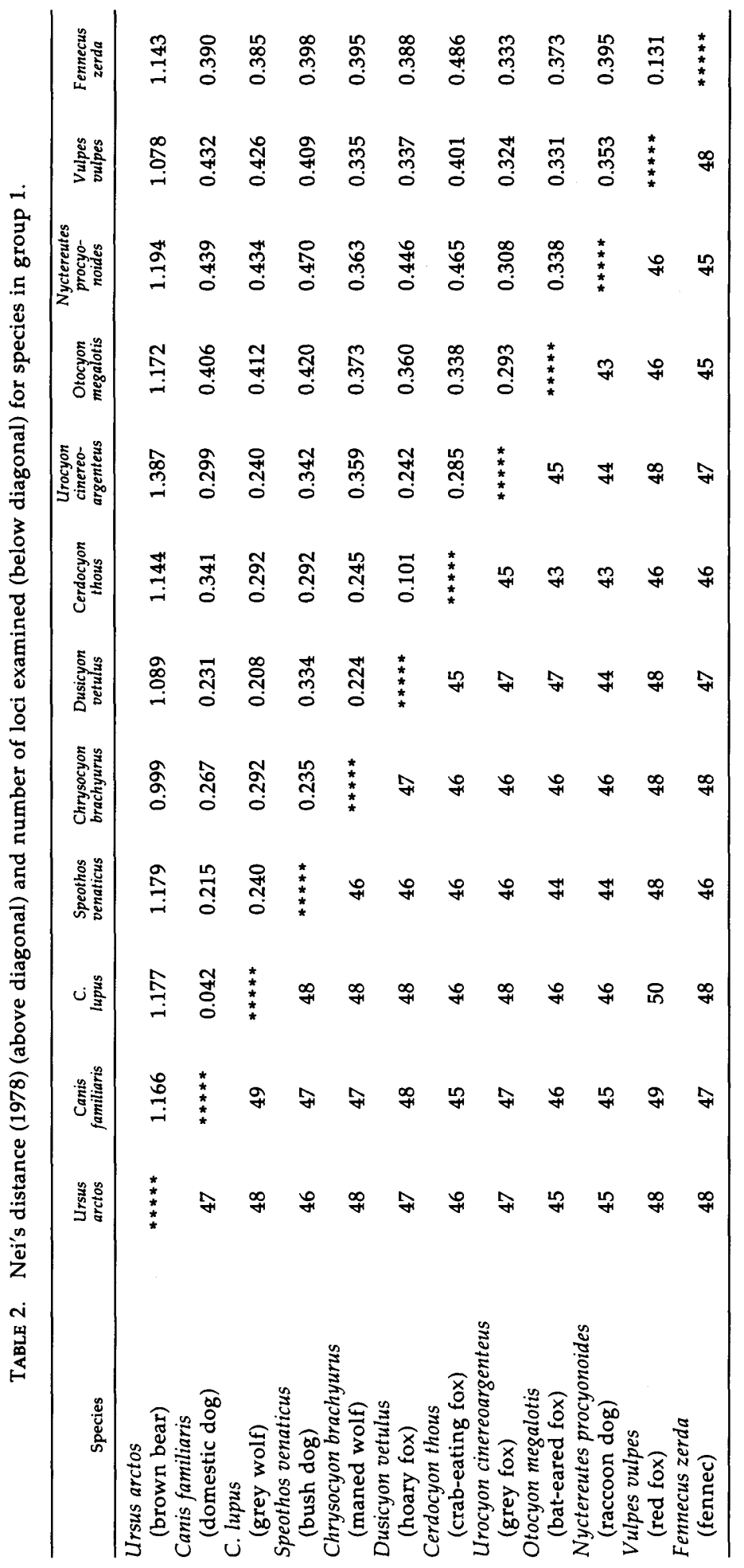



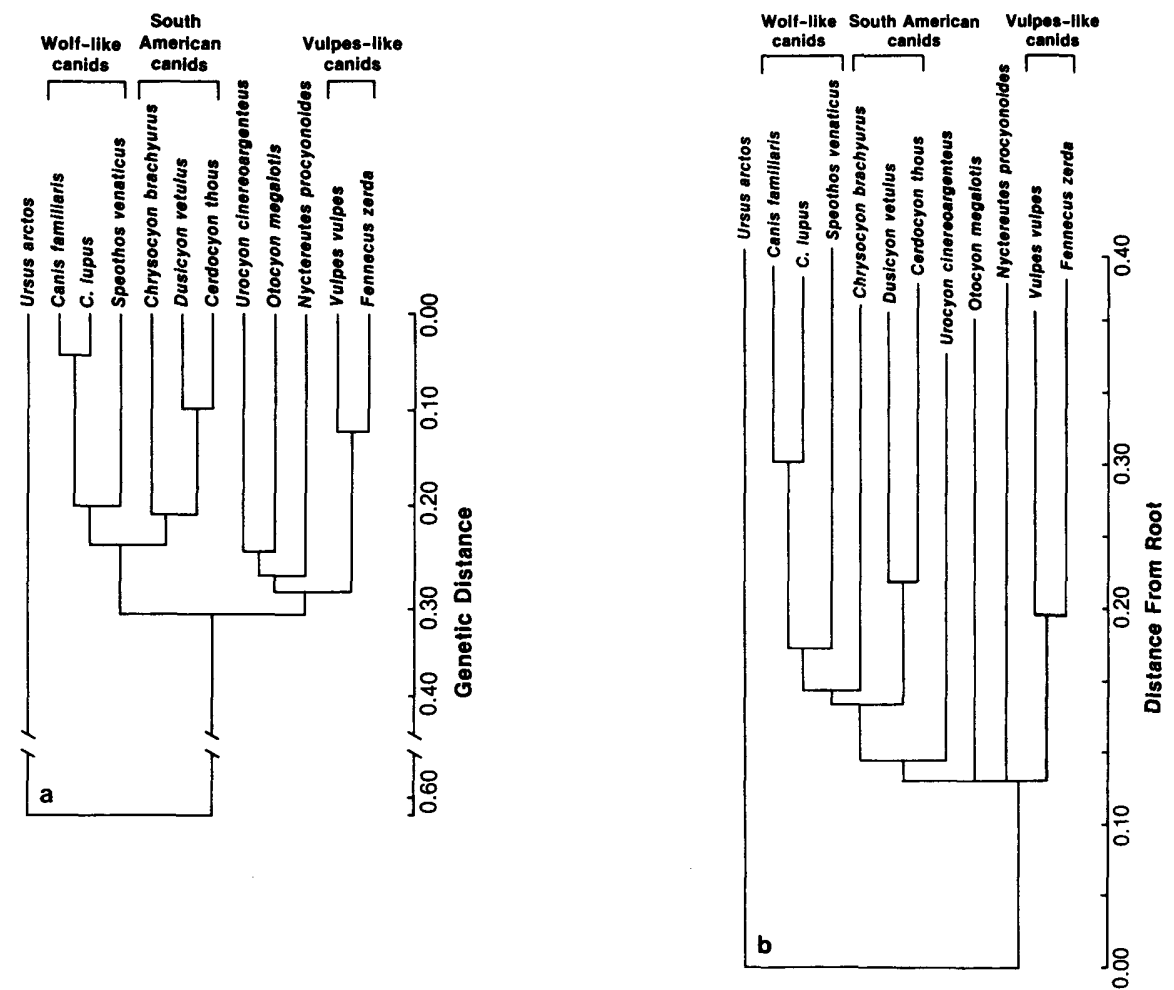

FIG. 1. a. UPGMA tree of the canids in group 1 based on Nei's distance (1978). Prager and Wilson's $F$-value $=7.1$, the cophenetic correlation coefficient $=0.98$. $b$. Distance-Wagner tree of the canids in group 1 based on Cavalli-Sforza and Edwards' (1967) chord distance. Prager and Wilson's F-value $=2.8$, the cophenetic correlation coefficient $=0.99$.

est distance occurred in comparisons of Otocyon, Urocyon, Nyctereutes and the other canids.

These distance values are reflected in the UPGMA phenogram and distance-Wagner tree (Fig. 1a, b), which exhibit broadly similar branching patterns. In both, Canis $\mathrm{fa}$ miliaris and C. lupus, Cerdocyon thous and Dusicyon vetulus, and Vulpes vulpes and Fennecus zerda are sister taxa. These species pairs are linked to other taxa so as to form several distinct groupings: the wolf-like canids, including Canis familiaris, C. lupus and at a low level of similarity, Speothos venaticus; the South American canids, including Dusicyon vetulus and Cerdocyon thous and, in the UPGMA tree, Chrysocyon brachyurus; and the Vulpes-like canids, including Vulpes vulpes and Fennecus zerda. In both trees, the wolf-like canids are most closely allied with the South American canids, together they possibly form a monophyletic grouping. The Vulpes-like canids are not closely associated with any other taxa in either tree. Similarly, species of the genera Otocyon, Urocyon and Nyctereutes are all genetically distinct and appear to have diverged early in the history of the family.

Differences between the UPGMA phenogram and the distance-Wagner tree concern the placement of the Urocyon lineage. The distance-Wagner tree suggests an unresolved tetrachotomy among Nyctereutes, Otocyon, the Vulpes-like canids and the group containing the wolf-like canids and the South American canids. The UPGMA tree agrees with the approximate three-way split of Nyctereutes, Otocyon and the Vulpeslike canids but does not associate Urocyon with the wolf-like canids or the South American canids. Because these nodes are 
TABLE 3. Nei's genetic distance (1978) (above diagonal) and number of loci examined (below diagonal) for species in group 2.

\begin{tabular}{|c|c|c|c|c|c|c|}
\hline \multicolumn{7}{|c|}{ Wolf-like canids } \\
\hline Species & $\begin{array}{c}\text { Canis } \\
\text { familiaris }\end{array}$ & C. lupus & C. latrans & C. mesomelas & Lycaon pictus & $\begin{array}{l}\text { Chrysocyon } \\
\text { brachyurus }\end{array}$ \\
\hline $\begin{array}{l}\text { Canis familiaris } \\
\text { (domestic dog) }\end{array}$ & $* * * * *$ & 0.013 & 0.050 & 0.176 & 0.131 & 0.203 \\
\hline $\begin{array}{l}\text { C. lupus } \\
\text { (grey wolf) }\end{array}$ & 44 & $* * * * *$ & 0.036 & 0.193 & 0.131 & 0.261 \\
\hline $\begin{array}{l}\text { C. latrans } \\
\text { (coyote) }\end{array}$ & 43 & 44 & $* * * * *$ & 0.240 & 0.084 & 0.264 \\
\hline $\begin{array}{l}\text { C. mesomelas } \\
\text { (black-backed jackal) }\end{array}$ & 36 & 36 & 36 & $* * * * *$ & 0.356 & 0.409 \\
\hline $\begin{array}{l}\text { Lycaon pictus } \\
\text { (African wild dog) } \\
\text { Chrysocyon brachyurus } \\
\text { (maned wolf) }\end{array}$ & 39 & 39 & 39 & 34 & $\begin{array}{c}* * * * * \\
35\end{array}$ & $\begin{array}{l}0.311 \\
* * * * *\end{array}$ \\
\hline Species & Fennecus zerda & \multicolumn{4}{|c|}{ Vulpes-like canids } & V. vulpes \\
\hline \multicolumn{7}{|l|}{ Fennecus zerda } \\
\hline $\begin{array}{l}\text { Alopex lagopus } \\
\text { (arctic fox) }\end{array}$ & 39 & $* * * * *$ & 0.220 & \multicolumn{2}{|c|}{0.105} & 0.128 \\
\hline \multicolumn{7}{|l|}{ Vulpes chama } \\
\hline $\begin{array}{l}V . \text { macrotis } \\
(\text { kit fox })\end{array}$ & 43 & 39 & 34 & \multicolumn{2}{|c|}{$* * * * *$} & 0.145 \\
\hline \multicolumn{7}{|l|}{$V$. vulpes } \\
\hline
\end{tabular}

close and because it is difficult to compare goodness-of-fit measures from trees that optimize different criteria it is uncertain which tree is better.

\section{Sample 2}

Genetic distance among the wolf-like canids.-Several other species are commonly associated taxonomically with Canis familiaris and C. lupus, and these include Canis latrans (coyote), Canis mesomelas (blackbacked jackal), and Lycaon pictus (African wild dog) (Clutton-Brock et al., 1976; Van Gelder, 1978; Nowak and Paradiso, 1983). Genetic distances among pairs of these wolf-like canids are generally small (Table $3)$. Overall, fewer loci were scored in this survey, which may have caused discrepancies in distance values between several taxa that are repeated in this survey (Chrysocyon/Canis familiaris, Chrysocyon/C. lupus, and C. familiaris /C. lupus; Tables 2, 3). Moreover, the number of informative loci among the wolf-like canids is fewer, only $13(29 \%)$ of the loci are polymorphic.
The most similar taxa are Canis familiaris and $C$. lupus (0.013), which are both similar to C. latrans $(0.036$, C. latrans /C. lupus; 0.050 , C. latrans $/ C$. familiaris; Table 3). The remaining taxa generally show distance values greater than 0.100 . Surprisingly, Canis mesomelas has relatively large genetic distance values between it and all the other wolf-like canids. As expected, the largest distance values are between Chrysocyon brachyurus and the other canid taxa.

Both the UPGMA phenogram and the distance-Wagner tree reflect these patterns of genetic similarity but differ from each other in the specifics of their branching order (Fig. 2). In both trees, Canis mesomelas diverged first followed by Lycaon pictus and C. latrans in the UPGMA tree. The distanceWagner tree unites Lycaon pictus and C. latrans as sister taxa whereas the phenogram does not. Canis familiaris is closely linked with C. lupus in both trees.

Genetic distances among the Vulpes-like canids. - Distance values are less variable among the Vulpes-like canids (Table 3). 


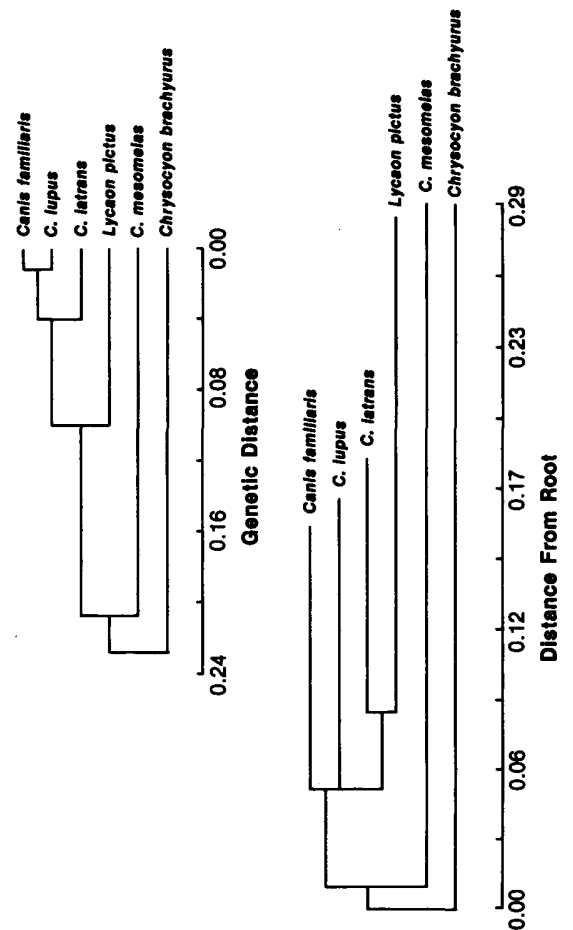

FIG. 2. UPGMA (left) and distance-Wagner (right) trees of the wolf-like canids in group 2 based, respectively, on Nei's distance (1978) and Cavalli-Sforza and Edwards' (1967) chord distance. The UPGMA and distance-Wagner trees of the wolf-like canids have, respectively, a Prager and Wilson's $F$ of 20.0 and 4.6 and a cophenetic correlation coefficent of 0.88 and 0.98 .

They range from 0.079 between $V u l p e s$ macrotis (kit fox) and Alopex lagopus (arctic fox) to 0.220 between $V$. chama (cape fox) and $A$. lagopus with a mean of 0.150 . Seventeen $(38 \%)$ of the loci are polymorphic among the vulpes-like canids. In both the UPGMA phenogram and distance-Wagner tree (Fig. 3), A. lagopus and V. macrotis are sister taxa. However, in the distance-Wagner tree the remaining taxa appear as an unresolved trichotomy radiating very close to the root of the tree. In the UPGMA phenogram, Fennecus zerda and Vulpes vulpes are placed in a group separate from that of $V$. chama and closest to a group containing Alopex lagopus and Vulpes macrotis.

\section{Consensus Tree and Absolute Time}

A time scale was added to a "strict" consensus tree (Rohlf, 1982) by assuming the
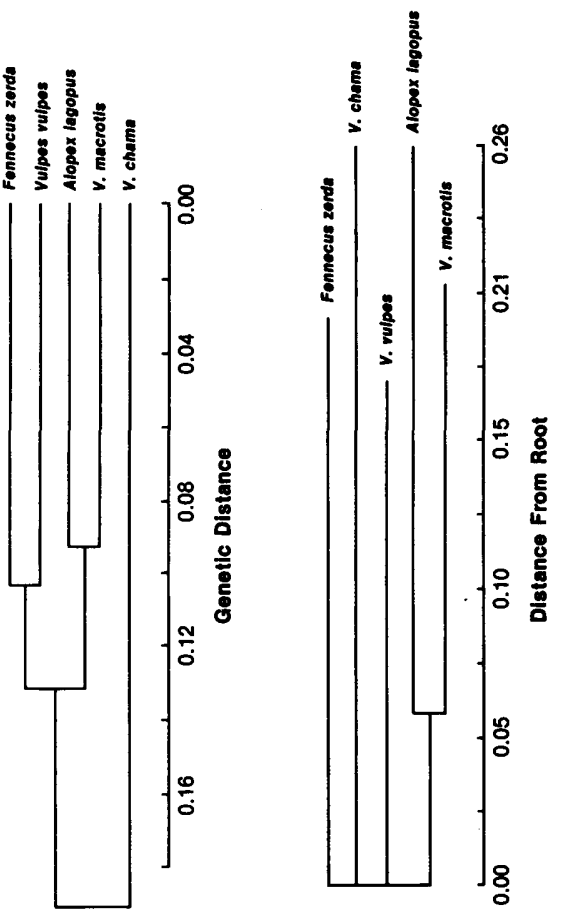

FIG. 3. UPGMA (left) and distance-Wagner (right) trees of the Vulpes-like canids in group 2 based, respectively, on Nei's distance (1978) and Cavalli-Sforza and Edwards' (1967) chord distance. The UPGMA and distance-Wagner trees of the Vulpes-like canids have, respectively, a Prager and Wilson's $F$ of 10.6 and 2.8 and a cophenetic correlation coefficent of 0.90 and 0.95 .

branching point between the wolf-like canids and the South American canids occurred approximately 7 MYBP (Fig. 4). This time is based on the first appearance of Canis davisii, the potential ancestor of both groups, in the North American fossil record (Berta, 1984). Assuming that this is a reasonable divergence time for these two groups, 0.1 genetic distance (Nei, 1978) units equals approximately 2.5 million years, which is similar to values estimated for other vertebrate groups (Avise and Aquadro, 1981; Thorpe, 1982). However, considerable variability in the rate of protein evolution has been found among vertebrates (Avise and Aquadro, 1982; Thorpe, 1982; Kessler and Avise, 1985; Britten, 1986; Vawter and Brown, 1986). Because Canidae is a closely-related family it is hoped that the variability in the rate of protein evo- 
lution among canid taxa is small. The constancy of protein evolution in the Canidae is suggested by the correspondence of divergence times and first appearance dates in the fossil record (see Discussion).

As with the previous family-wide trees three distinct lineages are suggested by the consensus tree: 1) the wolf-like canids including Canis, Lycaon and perhaps Speothos; 2) the South American canids, including Dusicyon and Cerdocyon and at a significantly greater level of divergence, Chrysocyon; and 3) the Vulpes-like canids, including Vulpes, Fennecus and Alopex. The remaining canid taxa (Otocyon, Urocyon and Nyctereutes) are not closely related to any of the canid species that were surveyed.

Among the wolf-like canids, differentiation began about $6 \mathrm{MYBP}$, and in our analysis is represented by an unresolved trichotomy among Speothos venaticus, Canis mesomelas and the remaining wolf-like canids (Fig. 4). The relative branching sequence of C. mesomelas and Speothos venaticus cannot be resolved because they were not included in the same survey (see Materials and Methods section). However, relative distance values suggest that Speothos is less closely allied to the C. lupus-C. familiaris group than is $C$. mesomelas (Tables $2,3)$. A second branching event occurred approximately $3 \mathrm{MYBP}$ and involved $L y$ caon pictus, $C$. latrans and the lineage leading to $C$. familiaris and C. lupus.

Among the South American canids Chrysocyon brachyurus is the earliest divergence at approximately 6.5 MYBP. The divergence of Dusicyon vetulus and Cerdocyon thous, approximately 2.5-3 MYBP, is roughly coincident with the opening of the Panamanian land bridge (Marshall et al., 1982, 1984). The genus Dusicyon includes five other species that were not available for analysis but are thought to be closely associated with Dusicyon vetulus (Langguth, 1969). The other endemic South American canid analyzed in this study, Speothos venaticus, appears not to be closely allied to the Dusicyon group.

Among the Vulpes-like canids only $V$. macrotis and $A$. lagopus are clustered together, their divergence time is approxi-

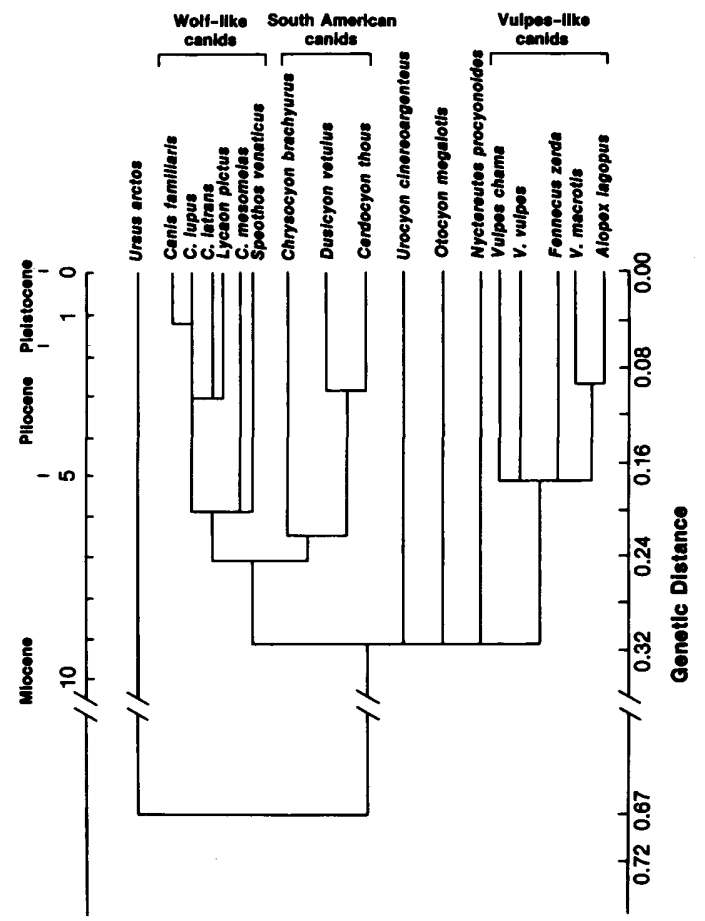

FIG. 4. A "strict" consensus tree (Rohlf, 1982) based on UPGMA and distance-Wagner trees of species in samples 1 and 2.

mately 2-3 MYBP. This cluster and the lineages leading to $V$. chama, $V$. vulpes, and Fennecus zerda diverged from each other approximately 5 MYBP.

\section{DISCUSSION}

\section{Evolution of the Trenchant Heel}

The direction of trenchant heel evolution depends on whether the presence of a trenchant heel on the carnassial tooth is viewed as a primitive or derived character for the wolf-like canids. The latter appears more likely because the trenchant heel is not present in the potential ancestors of the wolf-like canids (Kurten, 1968, 1974; Kurten and Anderson, 1980). If this is the case, the trenchant heel has apparently evolved independently in Speothos and $L y$ caon. Alternatively, if this condition is primitive then it was secondarily lost in the other wolf-like canids. This degree of evolutionary flexibility suggests that the 
trenchant heel condition may not be a highly conserved character.

Parallelism in both development of a trenchant heel and reduction of the postcarnassial molars may be the result of similar selective pressure for increased efficiency in processing meat (Ewer, 1973; Van Valkenburgh, in press). Lycaon and Cuon are large cursorial predators whose diet is predominately meat (Kingdon, 1977; Johnsingh, 1981). In both canids, trenchant heels are present on the carnassial and post-carnassial grinding molars are reduced, especially in Cuon. Surprisingly, the reduction of the post-carnassial molars is most extreme in the diminutive Speothos. The seemingly predacious dentition of Speothos is combined with a definitively non-cursorial skeleton: a long trunk with remarkably short, robust legs (Hildebrand, 1952, 1954; Langguth, 1969). This unusual combination of features has likely contributed to the confusion surrounding its diet and prey-killing behavior (Bates, 1944; Hildebrand, 1952; Langguth, 1969; Kitchener, 1971; Kleiman, 1972; Clutton-Brock et al., 1976; Brady, 1981; Deutsch, 1983). However, Speothos could be related to the extinct New World canid genus Protocyon which is much larger in body size (Berta, 1979; Kurten and Anderson, 1980). Speothos and Protocyon share several morphologic features including the presence of a trenchant heel. Thus, the apparent carnivorous dentition of Speothos could be only retained from a larger more carnivorous ancestor. Moreover, the phyletic decrease in body size that may have occurred in the evolution of Speothos could have resulted in other associated effects. Dwarfism has been observed in many mammal lineages to produce distinct allometric effects (cf. Marshall and Corruccini, 1978; Prothero and Sereno, 1982; Roth, 1984). For instance, small domestic dogs have relatively larger metatarsals than large dogs (Wayne, 1986b). Moreover, small animals may be mechanistically less able to accommodate morphologic features such as additional teeth or toes (Alberch, 1985). Thus, the unusual limb proportions and loss of post-carnassial teeth in Speothos might be a conse- quence of body size reduction or dwarfism rather than a specific dietary or locomotor adaptation.

\section{The Radiation of the \\ South American Canids}

Our results suggest that the diverse array of morphologies represented by the recent South American canids has a complex origin. Apparently, the long-legged maned wolf Chrysocyon is not closely related genetically to any canid examined in this survey and thus appears to represent the sole, terminal species of a 6-million-year-old lineage. No fossil or living intermediates exist to connect this morphologically aberrant species with ancestral fossil forms. Similarly, Speothos is not closely associated genetically with other recent South American canids analyzed in this survey and appears more closely associated with the wolf-like canids. Apparently, the lineages leading to Chrysocyon and Speothos were genetically distinct well before the opening of the Panamanian land bridge and the radiation of the fox-like South American canids.

The radiation of the South American foxes (the Dusicyon group and Cerdocyon thous) began approximately 2-3 MYBP, an example of rapid morphologic evolution. This radiation coincided with the opening of the Panamanian land bridge in the Pliocene and may have been fostered by the absence of eutherian terrestrial predators in South America (Patterson and Pascual, 1972; Simpson, 1980; Marshall et al., 1982).

\section{Relationship of These Results to Morphologic, Karyologic and Paleontologic Studies}

A detailed discussion of morphologic, karyologic and paleontologic studies of the Canidae is given in Wayne et al. (in press). These studies support many aspects of the tree presented in Figure 4. Specific areas of agreement and disagreement are outlined below.

Morphologic studies. - In general, qualitative and quantitative morphologic studies of the Canidae support the groupings represented in the consensus tree (Huxley, 
1880; Simpson, 1945; Lawrence and Bossert, 1967; Langguth, 1969; Clutton-Brock et al., 1976; Van Gelder, 1978; Nowak, 1979; Olsen, 1985; Wayne, 1986a, b). Specifically, the following elements are supported: 1) the close grouping of $C$. familiaris and $C$. lupus, and the clustering of these two taxa with $C$. latrans; 2 ) the close association of Dusicyon vetulus and Cerdocyon thous and their distant association with the other South American canids, Chrysocyon brachyurus and Speothos venaticus; 3 ) the association of species in Vulpes with Fennecus zer$\mathrm{da}$; and 4) the distant association of Urocyon, Nyctereutes, and Otocyon to other canid taxa. The primary areas of disagreement concern: 1) the large genetic distance between C. mesomelas and the other wolf-like canids; 2) the association of Speothos with the wolflike canids; and 3) close clustering of $V$. macrotis and Alopex lagopus. A cladistic tree of the South American canids presented by Berta (1984) differs principally from Figure 4 in that Speothos is shown as a sister taxon of Nyctereutes procyonoides. In her analysis, these taxa are part of a clade that includes Cerdocyon and Dusicyon.

Karyologic studies.-Standard and G-banded karyotypes have been described for many of the canids discussed in this study (Chiarelli, 1975; Wurster-Hill and Centerwall, 1982; Yoshida et al., 1983; Wayne et al., 1987a, b). Several groupings seen in Figure 4 are supported by the results of these studies: 1) the association of the wolf-like and South American canids, all of which have high diploid number karyotypes and a large number of small acrocentric chromosomes; 2) the association of Canis lupus, C. familiaris, C. latrans and Lycaon pictus, all of which share a derived diploid number of 78 and similar chromosome morphology; 3 ) the grouping of Cerdocyon thous with Dusicyon vetulus based on a common diploid number of 74 and extensive chromosome arm homology; 4) the close association of the Vulpes-like canids; except for Fennecus, all these canids have low-numbered karyotypes and a considerable degree of arm homology; 5) the close association between $V$. macrotis and Alopex, based on a unique, shared, G-band homologous karyotype; and 6) the distant association of Urocyon, Nyctereutes and Otocyon with other canids based on their unique karyotypes.

Paleontologic studies. - Both the time scale and branching order of Figure 4 are in large part supported by the fossil record. In agreement with Figure 4, the archaezoological record shows that C. familiaris is a very recent derivative of $C$. lupus (Scott, 1968; Epstein, 1971; Turnbull and Reed, 1974; Olsen, 1985). The common ancestor of these two taxa and $C$. latrans probably existed in the late Pliocene, 2 MYBP (Giles, 1960; Kurten, 1974; Nowak, 1979; Kurten and Anderson, 1980). The genus Lycaon first appears about 1.5 MYBP in Europe and Africa (Kurten, 1968; Savage and Russell 1983). The European species provides a potential link between the modern species and its presumed European C. lupus-like ancestors as suggested by Figure 4 . The earliest record of Dusicyon and Cerdocyon in South America is approximately 1-2 MYBP, which is in near agreement with the consensus tree (Berta, 1979, 1984). The first appearance of Speothos and Chrysocyon is late Pleistocene, which is more recent than suggested by the consensus tree (Berta, 1984). However, their fossil record is poor and Speothos may be a descendant of Protocyon that was present in the late Pliocene of the New World (Berta, 1979; Kurten and Anderson, 1980). The first recognized Vulpes species in the fossil record is midMiocene (9-12 MYBP), which supports the divergence time of the Vulpes-like canids from the other canid species shown in Figure 4 (Savage and Russell, 1983). Vulpes vulpes and $V$. chama have fossil records extending back to the early Pleistocene, 11.8 MYBP, and the other Vulpes-like canids all appear more recently, 0.5 to 1 MYBP (Kurten, 1968; Kurten and Anderson, 1980; Savage and Russell, 1983). Figure 4 suggests earlier times of first appearance for these taxa. Finally, the fossil record of Urocyon, Nyctereutes, and Otocyon supports relatively early times of origination as suggested by Figure 4. Nyctereutes first appears $5 \mathrm{MYBP}$ in the European fossil record, and Urocyon appears in the late Hemphillian, 
4-6 MYBP (Kurten and Anderson, 1980; Savage and Russell, 1983; Berta, 1984). Otocyon has a sparse fossil record that extends as far back as the late Pliocene, 2 MYBP, of North Africa (Savage and Russell, 1983).

\section{ACKNOWLEDGMENTS}

We thank the veterinary and curatorial staff of the zoos listed in Table 1. Without their help this study would not have been possible. We especially appreciate the efforts of Drs. Mitchell Bush, Lindsey Phillips, and Jo Gayle Howard of the National Zoological Park in Washington, D.C. who provided essential material and assistance. Annalisa Berta, Audrone Biknevicius, Michael Braun, Donald Buth, Sarah George, Jan Martenson, William Modi, Donald Savage, Blaire Van Valkenburgh and Phillip Youngman provided critical review and discussion of this manuscript.

\section{REFERENCES}

AlbERCH, P. 1985. Developmental constraints: Why St. Bernards often have an extra digit and poodles never do. Am. Nat., 126:430-433.

Avise, J. C., AND C. F. Aquadro. 1981. A comparative summary of genetic distances in vertebrates: Patterns and correlations. Evol. Biol., 14:151-285.

BATES, M. 1944. Notes on captive Icticyon. J. Mammalogy, 25:152-154.

BERTA, A. 1979. Quaternary evolution and biogeography of the larger South American Canidae (Mammalia: Carnivora). Ph.D. Dissertation, Univ. California, Berkeley.

Berta, A. 1984. The Pleistocene bush dog, Speothos pacivorus (Canidae) from the Lagoa Santa caves, Brazil. J. Mammalogy, 65:549-559.

BRADY, C. A. 1981. The vocal repertoires of the bushdog (Speothos venaticus), crab-eating fox (Cerdocyon thous) and the maned wolf (Chrysocyon brachyurus). Anim. Behav., 29:649-669.

BRITTEN, R. J. 1986. Rates of DNA sequence evolution differ between taxonomic groups. Science, 231: 1393-1398.

Cavalli-Sforza, L. L., AND A. W. F. EdWards. 1967. Phylogenetic analysis: Models and estimation procedures. Evolution, 21:550-570.

Chiarelli, A. B. 1975. The chromosomes of the Canidae. Pages 40-53 in The wild canids: Their systematics, behavioral ecology, and evolution (M. W. Fox, ed.). Van Nostrand Reinhold, New York.

Clutton-Brock, J., G. B. CoRbEt, AND M. Hills. 1976. A review of the family Canidae with a classification by numerical methods. Bull. Brit. Mus. (Nat. Hist.), Zool., 29:117-199.

DEUTSCH, L. A. 1983. An encounter between bush dog (Speothos venaticus) and Paca (Agouti paca). J. Mammalogy, 64:532-533.

DUTRILlaUX, B. 1986. Evolution chromosomique chez les primates, les carnivores et les rongeurs. Mammalia, 50:120-162.

EPSTEIN, H. 1971. The origins of the domestic ani- mals of Africa. Volume 1. Africana Publ. Co., New York.

EWER, R. F. 1973. The carnivores. Widenfeld and Nicolson, London.

FARRIS, J. S. 1981. Distance data in phylogenetic analysis. Pages 3-23 in Advances in cladistics: Proceedings of the first meeting of the Willi Hennig Society (V. A. Funk and D. R. Brooks, eds.). New York Botanical Garden, New York.

FARRIS, J. S. 1985. Distance data revisited. Cladistics, 1:67-85.

FARRIS, J. S. 1986. Distance and statistics. Cladistics, 2:144-157.

FELSENSTEIN, J. 1984. Distance methods for inferring phylogenies: A justification. Evolution, 38:16-24.

FELSENSTEIN, J. 1986. Distance methods: A reply to Farris. Cladistics, 2:130-143.

Fisher, R. A., W. PuTt, AND E. HaCkEL. 1976. An investigation of the products of 53 gene loci in three species of wild Canidae: Canis lupus, Canis latrans, and Canis familiaris. Biochemical Genetics, 14:963974.

GILES, E. 1960. Multivariate analysis of Pleistocene and Recent coyotes (Canis latrans) from California. Univ. Calif. Publ. Geol. Sci., 36:369-390.

GormAN, G. C., AND J. RENZI. 1979. Genetic distance and heterozygosity estimates in electrophoretic studies: Effects of sample size. Copeia, 1979:242249.

HARRIS, H., AND D. A. HOPKINSON. 1976. Handbook of enzyme electrophoresis in human genetics. North Holland Publ. Co., Amsterdam.

HEDGES, S. B. 1986. An electrophoretic analysis of Holarctic hylid frog evolution. Syst. Zool., 35:1-21.

HiLDEBRAND, M. 1952. An analysis of body proportions in the Canidae. Amer. J. Anat., 90:217-256.

Hildebrand, M. 1954. Comparative morphology of the body skeleton in the Recent Canidae. Univ. Calif. Publ. Zool., 52:399-470.

Hsu, K. J., J. la BrecQue, S. F. Percival, R. C. Wright, A. M. Gombose, K. Pisciotto, P. Tucker, N. PeTERSON, J. A. MCKENZIE, H. WEISSERT, A. M. KARPOFF, M. F. CARMAN, JR., AND E. SCHREIBER. 1984. Numerical age of the Cenozoic biostratigraphic datum levels: Results of the South Atlantic drilling. Geol. Soc. Amer. Bull., 95:863-876.

HuXLEY, T. H. 1880. On the cranial and dental characters of the Canidae. Proc. Zool. Soc. Lond., XVI: 238-288.

JOHNSINGH, A. J. T. 1981. Ecology and behaviour of the dhole or the indian wild dog, Cuon alpinus, with special reference to predator-prey relationships at Bandipur. Ph.D. Dissertation, Madurai Kamaraj Univ., Bongalore.

Kessler, L. G., AND J. C. AVISE. 1985. A comparative description of mitochondrial DNA in selected avian and other vertebrate genera. Mol. Biol. Evol., 2:109126.

KINGDON, J. 1977. East African mammals. Volume 3, pt. A (Carnivores). Academic Press, London.

KITCHENER, S. 1971. Observations on the breeding of the bush dog at Lincoln Park Zoo, Chicago. Internatl. Zoo. Yearbk., 11:99-100. 
KLeimaN, D. G. 1972. Social behavior of the maned wolf (Chrysocyon brachyurus) and bush dog (Speothos venaticus): A study in contrast. J. Mammalogy, 53: 791-806.

KuRTEN, B. 1968. Pleistocene mammals of Europe. Aldine Publ. Co., Chicago.

KURTEN, B. 1974. A history of coyote-like dogs in North America (Canidae, Mammalia). Acta Zool. Fennica, 140:1-38.

Kurten, B., AND E. ANDERSON. 1980. Pleistocene mammals of North America. Columbia Univ. Press, New York.

LANGGUTH, A. 1969. Die sudamerikanischen Canidae unter besonderer Berucksichtigung des Mahnenwolfes Chrysocyon brachyurus Illiger. Zeit. Wissenschaftliche Zool., 179:1-188.

LANGGUTH, A. 1975. Ecology and evolution in the South American canids. Pages 192-206 in The wild canids: Their systematics, behavioral ecology and evolution (M. W. Fox, ed.). Van Nostrand Reinhold Co., New York.

LARSON, A. 1984. Neontological inferences of evolutionary pattern and process in the salamander family Plethodontidae. Evol. Biol., 17:119-217.

LAWRENCE, B., AND W. H. BOSSERT. 1967. Multiple character analysis of Canis lupus, latrans, and familiaris, with a discussion of the relationship of Canis niger. Amer. Zool., 7:223-232.

MARSHALl, L. G., A. BERTA, R. HoffstetTER, R. PASCUAL, O. A. REIG, M. Bombin, AND A. MONES. 1984. Mammals and stratigraphy: Geochronology of the continental mammal-bearing Quaternary of South America. Palaeovertebrata, 1984:1-76.

MARSHALl, L. G., AND R. S. CORRUCCINI. 1978. Variability, evolutionary rates, and allometry in dwarfing lineages. Paleobiology, 4:101-119.

Marshall, L. G., S. D. WebB, J. J. SEPKOSKI, AND D. M. RAUP. 1982. Mammalian evolution and the great American interchange. Science, 215:1351-1357.

MCAlpine, P. J., T. B. Shows, R. L. MilleR, AND A. J. PAKSTIS. 1985. The 1985 catalog of mapped genes and report of nomenclature committee. Cytogenetic and Cell Genetics, 40:8-66.

NEI, M. 1977. F-statistics and the analysis of gene diversity in sub-divided populations. Ann. Human Genet., 41:225-233.

NEI, M. 1978. Estimation of average heterozygosity and genetic distance from a small number of individuals. Genetics, 89:583-590.

NeI. M., F. TAJima, AND Y. TATENO. 1983. Accuracy of estimated phylogenetic trees from molecular data. J. Mol. Evol., 19:153-170.

NowAK, R. M. 1979. North American Quaternary Canis. Monogr. Mus. Nat. Hist. Univ. Kansas, no. 6, 154 pp.

NowAK, R. M., AND J. L. PARAdIso. 1983. Walker's mammals of the world. Volume 2. The Johns Hopkins Univ. Press, Baltimore.

OLSEN, S. J. 1985. Origins of the domestic dog: The fossil record. Univ. Arizona Press, Tucson.

Patterson, B., AND R. Pascual. 1972. The fossil mammal fauna of South America. Pages 247-309 in Evolution, mammals and southern continents (A.
Keast, F. C. Erk, and B. Glass, eds.). State Univ. N.Y. Press, Albany.

Prager, E. M., AND A. C. Wilson. 1976. Congruency of phylogenies derived from different proteins. A molecular analysis of the phylogenetic position of cracid birds. J. Mol. Evol., 9:45-57.

Prothero, D. R., AND P. C. SERENO. 1982. Allometry and paleoecology of medial Miocene dwarf rhinoceroses from the Texas Gulf Coastal Plain. Paleobiology, 8:16-30.

ROGERS, J. S. 1972. Measures of genetic similarity and genetic distance. Studies in Genetics, Univ. Texas Publ., 7213:145-153.

RoHLF, F. J. 1982. Consensus indices for comparing classifications. Math. Biosci., 59:131-144.

Roth, V. L. 1984. How elephants grow: Heterochrony and the calibration of developmental stages in some living and fossil species. J. Vert. Paleo., 4: 126-145.

SARICH, V. M. 1977. Rates, sample sizes, and the neutrality hypothesis for electrophoresis in evolutionary studies. Nature, 264:24-28.

SAVAGE, D. E., AND D. E. Russell. 1983. Mammalian paleofaunas of the world. Addison-Wesley Publ. Co., London.

Savage, R. J. G. 1978. Carnivora. Pages 249-267 in Evolution of African mammals (V. J. Maglio and H. B. S. Cooke, eds.). Harvard Univ. Press, Cambridge.

ScOTT, J. P. 1968. Evolution and domestication of the dog. Evol. Biol., 2:243-275.

SHAFFER, H. B. 1984. Evolution in a paedomorphic lineage. I. An electrophoretic analysis of the Mexican ambystomatid salamanders. Evolution, 38:12071218.

SIMONSEN, V. 1976. Electrophoretic studies on the blood proteins of domestic dogs and other Canidae. Hereditas, 82:7-18.

SIMPSON, G. G. 1945. The principles of classification and a classification of the mammals. Bull. Amer. Mus. Nat. Hist., 85:i-xvi + 1-350.

SIMPSON, G. G. 1980. Splendid isolation. The curious history of South American mammals. Yale Univ. Press, New Haven.

SNEATH, P. H. A., AND R. R. SOKAL. 1973. Numerical taxonomy. W. H. Freeman, San Francisco.

STAINS, H. J. 1975. Distribution and taxonomy of the Canidae. Pages 3-26 in The wild canids: Their systematics, behavioral ecology and evolution (M. W. Fox, ed.). Van Nostrand Reinhold Co., New York.

SWOFFORD, D. L. 1981. On the utility of the distance Wagner procedure. Pages 25-43 in Advances in cladistics. Proceedings of the first meeting of the Willi Hennig Society (V. A. Funk and D. R. Brooks, eds.). New York Botanical Garden, New York.

SWOFFORD, D. L., AND R. B. SELANDER. 1981. BIOSYS-1: A FORTRAN program for the comprehensive analysis of electrophoretic data in population genetics and systematics. J. Hered., 72:281-283.

THORPE, J. P. 1982. The molecular clock hypothesis: Biochemical evolution, genetic differentiation and systematics. Ann. Rev. Ecol. Syst., 13:139-168.

Turnbull, P. F., AND C. A. ReED. 1974. The fauna 
from the terminal Pleistocene of Palegawra cave. Fieldiana Anthropology, 63:81-146.

VAN GELDER, R. G. 1978. A review of canid classification. Amer. Mus. Novitates, 2646:1-10.

VAN VALKENBURGH, B. 1985. Locomotor diversity in past and present guilds of large predator mammals. Paleobiology, 11:406-428.

VAN VALKENBURGH, B. 1987. Skeletal indicators of locomotor behavior in living and extinct carnivores. J. Vert. Paleo., 7:67-129.

VAN VAlKenburGH, B. In press. Carnivore dental adaptations and diet. A study of trophic diversity within guilds. In Carnivore behavior, ecology, and evolution (J. Gittleman, ed.). Cornell Univ. Press, Ithaca.

VAWTER, L., AND W. M. BROWN. 1986. Nuclear and mitochondrial DNA comparisons reveal extreme rate variations in the molecular clock. Science, 234: 194-196.

WAKE, D. B., AND K. P. YANEV. 1986. Geographic variation in allozymes in a "ring species" the plethodontid salamander Ensatina eschscholtzii of western North America. Evolution, 40:702-715.

WAYNE, R. K. 1986a. Cranial morphology of domestic and wild canids: The influence of development on morphologic change. Evolution, 40:243-261.
WAYNE, R. K. 1986b. Limb morphology of domestic and wild canids: The influence of development on morphologic change. J. Morphology, 187:301-319.

WAYNE, R. K., R. E. BEVENISTE, AND S. J. O'BRIEN. In press. Phylogeny and evolution of the Carnivora and carnivore families. In Carnivore behavior, ecology, and evolution (J. L. Gittleman, ed.). Cornell Univ. Press, Ithaca.

WAYNE, R. K., W. G. NASH, AND S. J. O'BRIEN. 1987a. Chromosomal evolution of the Canidae: I. Species with high diploid numbers. Cytogenetics and Cell Genetics, 44:123-133.

WAYNE, R. K., W. G. NASH, AND S. J. O'BRIEN. 1987 b. Chromosomal evolution of the Canidae: II. Species with low diploid numbers. Cytogenetics and Cell Genetics, 44:134-141.

WURSTER-HILl, D. H., AND W. R. CenterWALl. 1982. The interrelationships of chromosome banding patterns in canids, mustelids, hyena, and felids. Cytogenetics and Cell Genetics, 34:178-192.

Yoshida, M. A., N. TAKAGI, AND M. SASAKI. 1983. Karyotypic kinship between the blue fox (Alopex lagopus Linn.) and the silver fox (Vulpes fulva Desm.). Cytogenetics and Cell Genetics, 35:190-194.

Received 15 October 1986; accepted 4 September 1987. 
APPENDIX 1. Gene-enzyme systems examined. Gene symbols are for homologous (where possible) symbols recommended by the nomenclature committee of the VIIIth International Workshop on Human Gene Mapping (McAlpine et al., 1985). The basis of homology with human systems is defined by Harris and Hopkinson (1976). Four buffer systems were employed and these include: 1) TEB: electrode, $0.18 \mathrm{M}$ tris, $0.004 \mathrm{M}$ EDTA, $0.1 \mathrm{M}$ boric acid $\mathrm{pH} 8.6$; gel $0.1 \times$ of electrode buffer; 2) TC: electrode $0.14 \mathrm{M}$ tris, $0.043 \mathrm{M}$ citric acid pH 7.1 ; gel $0.07 \times$ of electrode buffer; 3) TEM: electrode, $0.1 \mathrm{M}$ tris, $0.01 \mathrm{M}$ EDTA, $0.1 \mathrm{M}$ maleic acid, $0.01 \mathrm{M} \mathrm{MgCl}_{2}$ pH 7.4; gel $0.1 \times$ of electrode buffer; 4) TG: electrode 0.005 tris, $0.039 \mathrm{M}$ glycine pH $8.9 ;$ gel $0.37 \mathrm{M}$ tris $\mathrm{HCl}$ pH 8.9. Tissues used: $R=$ red blood cells; $L=$ lymphocytes; $C=$ transformed cultured cells.

\begin{tabular}{|c|c|c|c|c|}
\hline Enzyme & $\begin{array}{l}\text { IUPAC- } \\
\text { IUB No. }\end{array}$ & Gene symbol & Buffer system & Tissue used \\
\hline 1. Acid phosphatase-1 & 3.1.3.2 & ACP1 & TC & $\mathrm{R}, \mathrm{C}$ \\
\hline 2. Acid phosphatase-2 & 3.1.3.2 & ACP2 & $\mathrm{TC}$ & $\mathrm{R}, \mathrm{L}, \mathrm{C}$ \\
\hline 3. Adenosine deaminase & 3.5.4.4 & ADA & TEB & $\mathrm{L}, \mathrm{C}$ \\
\hline 4. Adenine phosphoribosyl transferase & 2.4.2.7 & APRT & TG & $\mathbf{R}$ \\
\hline 5. Adenylate kinase- 1 & 2.7 .4 .3 & AK1 & $\mathrm{TC}$ & $\mathrm{R}, \mathrm{L}, \mathrm{C}$ \\
\hline 6. Aminoacylase-1 & & ACY1 & TC & $\mathrm{L}, \mathrm{C}$ \\
\hline 7. Carbonic anhydrase- 1 & 4.2.1.1 & CA1 & TEB & $\mathbf{R}$ \\
\hline 8. Carbonic anhydrase-2 & 4.2.1.1 & CA2 & TEB & $\mathbf{R}$ \\
\hline 9. Catalase & 1.11.1.6 & CAT & TEB & $\mathbf{R}$ \\
\hline 10. Creatine kinase- $B$ & 2.7.3.2 & CKBB & TEB & $\mathbf{R}, \mathbf{L}, \mathbf{C}$ \\
\hline 11. Diaphorase 1 & 1.6 .4 .3 & DIA1 & TEB & $\mathrm{R}, \mathrm{L}, \mathrm{C}$ \\
\hline 12. Diaphorase 4 & 1.6.4.3 & DIA4 & TEB & R, L, C \\
\hline 13. Esterase & 3.1.1.1 & ES1 & $\mathrm{TC}$ & $\mathrm{R}, \mathrm{L}, \mathrm{C}$ \\
\hline 14. Esterase & 3.1.1.1 & ES2 & TC & $\mathbf{R}, \mathrm{L}, \mathrm{C}$ \\
\hline 15. Glutamate oxaloacetate transaminase (soluble) & 2.6.1.1 & GOT1 & TEB/TEM & $\mathrm{L}, \mathrm{C}$ \\
\hline 16. Glutamate oxaloacetate transaminase (soluble) & -2.6.1.1 & GOT2 & TEB/TEM & L, C \\
\hline 17. Glucose-6-phosphate dehydrogenase & 1.1.1.49 & G6PD & TEB & $\vec{R}, \mathrm{~L}, \mathrm{C}$ \\
\hline 18. Glutamate pyruvate transaminase & 2.6.1.2 & GPT & $\mathrm{TC}$ & $\mathbf{R}, \mathbf{C}$ \\
\hline 19. Glucose phosphate isomerase & 5.3.1.9 & GPI & TEB & R, L, C \\
\hline 20. Glutathione reductase & 1.6.4.2 & GSR & TEB & $R, L, C$ \\
\hline 21. $\beta$-glucuronidase & 3.2.1.31 & GUSB & $\mathrm{TC}$ & $\mathrm{R}, \mathrm{L}, \mathrm{C}$ \\
\hline 22. Glyoxylase-1 & 4.4.1.5 & GLO1 & TEB & $\mathrm{R}, \mathrm{C}$ \\
\hline 23. Hexosaminidase-A & 3.2.1.30 & HEXA & TEB & $R, L, C$ \\
\hline 24. Hexokinase-1 & 2.7.1.1 & HK1 & TEB & $\mathrm{R}, \mathrm{L}, \mathrm{C}$ \\
\hline 25. Hexokinase-2 & 2.7.1.1 & HK2 & TEB & $\mathrm{R}, \mathrm{L}, \mathrm{C}$ \\
\hline 26. Isocitrate dehydrogenase-1 (soluble) & 1.1.1.42 & IDH1 & $\mathrm{TC}$ & $R, L, C$ \\
\hline 27. Isocitrate dehydrogenase-2 (mitochondrial) & 1.1.1.42 & IDH2 & $\mathrm{TC}$ & $\mathrm{R}, \mathrm{L}, \mathrm{C}$ \\
\hline 28. Inosine triphosphatase & 3.6.1.3 & ITPA & TEB & $\mathbf{R}, \mathrm{L}, \mathrm{C}$ \\
\hline 29. Lactate dehydrogenase-A & 1.1.1.27 & LDHA & $\mathrm{TC}$ & $\mathrm{R}, \mathrm{L}, \mathrm{C}$ \\
\hline 30. Lactate dehydrogenase-B & 1.1.1.27 & LDHB & $\mathrm{TC}$ & $\mathrm{R}, \mathrm{L}, \mathrm{C}$ \\
\hline 31. Malate dehydrogenase-1 (soluble) & 1.1.1.37 & MDH1 & TC & $\mathrm{R}, \mathrm{L}, \mathrm{C}$ \\
\hline 32. Malate dehydrogenase-2 (mitochondrial) & 1.1.1.37 & MDH2 & $\mathrm{TC}$ & $R, L, C$ \\
\hline 33. Malic enzyme-1 (soluble) & 1.1.1.40 & ME1 & $\mathrm{TC}$ & $\mathrm{R}, \mathrm{L}, \mathrm{C}$ \\
\hline 34. Mannose phosphate isomerase & 5.3 .1 .8 & MPI & TEB & $R, \vec{L}, \mathrm{C}$ \\
\hline 35. Nucleoside phosphorylase & 2.4.2.1 & NP & $\mathrm{TC}$ & $\mathrm{R}, \mathrm{L}, \mathrm{C}$ \\
\hline 36. Peptidase B & 3.4.11. & PEPB & $\mathrm{TC}$ & $\mathbf{R}, \mathrm{L}, \mathrm{C}$ \\
\hline 37. Peptidase C & 3.4.16. & PEPC & $\mathrm{TC}$ & $R, L, C$ \\
\hline 38. Peptidase D & 3.4.11. & PEPD & $\mathrm{TC}$ & $\mathrm{R}, \mathrm{L}, \mathrm{C}$ \\
\hline 39. Phosphyoglyceromutase- $A$ & 2.7.5.3 & PGAM & TC & $\mathrm{R}, \mathrm{C}$ \\
\hline 40. 6-Phosphogluconate dehydrogenase & 1.1.1.43 & PGD & TEB/TC & $\mathrm{R}, \mathrm{L}, \mathrm{C}$ \\
\hline 41. Phosphoglucomutase-1 & 2.7.5.1 & PGM1 & TC & R, L, C \\
\hline 42. Phosphoglucomutase-2 & 2.7.5.1 & PGM2 & $\mathrm{TC}$ & $\mathrm{R}, \mathrm{L}, \mathrm{C}$ \\
\hline 43. Phosphoglucomutase- 3 & 2.7.5.1 & PGM3 & TC & $R, L, C$ \\
\hline 44. Pyruvate kinase-1 & 2.7.1.40 & PKM1 & TEB & $\mathrm{R}, \mathrm{C}$ \\
\hline 45. Pyruvate kinase-2 & 2.7.1.40 & PKM2 & TEB & $\mathrm{R}, \mathrm{C}$ \\
\hline 46. Pyrophosphatase (inorganic) & 3.6.1.1 & PP & TEM & R, L, C \\
\hline 47. Superoxide dismutase- 1 & 1.15.1.1 & SOD1 & TEB & $\mathrm{R}, \mathrm{L}, \mathrm{C}$ \\
\hline 48. Transferrin & & TF & TG & serum \\
\hline 49. Triosephosphate isomerase & 5.3.1.1 & TPI & TEM & $\mathrm{R}, \mathrm{L}, \mathrm{C}$ \\
\hline 50. Albumin & & ALB & TG & serum \\
\hline 51. Hemogloblin & & HB & TEB & $\mathbf{R}$ \\
\hline
\end{tabular}


APPENDIX 2. Allozyme variation in the Canidae. Polymorphisms are scored separately in groups 1 and 2. Hence alleles may not be homologous between equivalent loci of the two groups. Dash indicates missing data. See Table 1 for definition of species codes.

\begin{tabular}{|c|c|c|c|c|c|c|c|c|c|c|c|c|}
\hline \multirow[b]{2}{*}{ Gene symbol } & \multicolumn{12}{|c|}{ Group 1} \\
\hline & Uar & $\mathrm{Cfa}$ & $\mathrm{Clu}$ & Cbr & Sve & Dve & Cth & Uci & Ome & Npr & $\begin{array}{l}\mathbf{v u} u \\
\end{array}$ & Fze \\
\hline 1. ACP1 & B & A & A & A & A & A & A & A & C & A & A & A \\
\hline 2. ACP2 & B & A & $\mathrm{A} / \mathrm{C}$ & A & A & A & D & A & A & A & $\mathbf{A}$ & A \\
\hline 3. ADA & B & A & A & A & A & A & A & A & A & - & C & C \\
\hline 4. APRT & B & A & $\mathbf{A}$ & A & A & A & A & $\mathrm{C}$ & A & A & A & A \\
\hline 5. AK1 & A & A & B & A & A & B & B & B & A & A & A & A \\
\hline 6. ACY1 & - & $\mathrm{A}$ & A & - & C & A & - & $\mathbf{A}$ & A & - & B & - \\
\hline 7. CA1 & A & A & A & A & A & A & A & A & A & A & A & A \\
\hline 8. CA2 & B & A & A & A & A & A & A & $\mathbf{A}$ & A & B & A & A \\
\hline 9. CAT & A & A & A & A & A & A & A & B & A & A & $\mathbf{A}$ & A \\
\hline 10. CKBB & B & A & A & A & A & A & A & A & A & A & A & C \\
\hline 11. DIA1 & A & A & A & - & $\mathrm{A} / \mathrm{B}$ & $\mathrm{A} / \mathrm{C}$ & C & A & - & - & $\mathrm{A} / \mathrm{C}$ & $A / D$ \\
\hline 12. DIA4 & B & A & A & A & A & A & A & A & $\mathbf{A}$ & A & A & A \\
\hline 13. ES1 & B & A & A & A & A & $\mathrm{A} / \mathrm{C}$ & A & A & A/D & A & A & A \\
\hline 14. ES2 & B & C & C & A & A & A & $\mathbf{A}$ & $\mathrm{D}$ & - & $\mathrm{E}$ & $\mathrm{E}$ & $\mathrm{E}$ \\
\hline 15. GOT1 & B & A & A & C & A & C & A & $\mathbf{A}$ & A & A & C & - \\
\hline 16. GOT2 & B & A & A & A & A & A & A & A & A & A & C & C \\
\hline 17. G6PD & A & A & A & A & B & A & A & A & A & A & A & B \\
\hline 18. GPT & B & A & A & A & A & - & A & A & - & A & C & C \\
\hline 19. GPI & B & $\mathrm{A}$ & A & C & A & C & $\mathrm{C}$ & C & C & C & C & C \\
\hline 20. GSR & B & A & A & A & A & A & A & A & A & C & A & A \\
\hline 21. GUSB & A & A & A & A & A & A & A & B & B & B & A & A \\
\hline 22. GLO1 & B & $\mathrm{A}$ & A & B & A & A & A & A & A & A & A & A \\
\hline 23. HEXA & B & A & A & A & - & A & - & C & D & A & $\mathrm{E}$ & D \\
\hline 24. HK1 & A & $\mathrm{A}$ & A & A & A & A & A & A & A & A & A & A \\
\hline 25. HK2 & A & - & A & A & A & - & $\mathbf{A}$ & A & - & A & A & A \\
\hline 26. IDH1 & B & A & A & A & A & A & A & A & A & A & A & A \\
\hline 27. IDH2 & B & A & A & A & $\mathrm{C}$ & A & A & A & A & A & A & A \\
\hline 28. ITPA & B & - & B & $\mathrm{A}$ & A & B & - & A & A & A & A & A \\
\hline 29. LDHA & A & A & A & $\mathrm{A}$ & A & A & A & A & A & A & A & A \\
\hline 30. LDHB & B & B & B & B & B & A & A & $\mathbf{A}$ & A & A & A & A \\
\hline 31. MDH1 & A & A & A & A & A & A & A & A & A & A & A & A \\
\hline 32. $\mathrm{MDH} 2$ & B & $\mathrm{A}$ & A & A & A & A & A & $\mathrm{A} / \mathrm{C}$ & A & - & A & A \\
\hline 33. ME1 & B & $\mathrm{A}$ & A & A & $\mathrm{C}$ & D & $\mathrm{D}$ & $\mathrm{E}$ & $\mathbf{F}$ & $\mathrm{E}$ & $\mathrm{E}$ & $\mathrm{E}$ \\
\hline 34. MPI & A & B. & B & A & A & A & A & A & A & A & A & A \\
\hline 35. NP & B & $\mathrm{A}$ & A & $\mathrm{A}$ & A & A & A & A & A & B & A & A \\
\hline 36. РEPB & B & A & A & C & C & A & C & A & A & A & A & $\mathbf{A}$ \\
\hline 37. PEPC & B & $\mathrm{A}$ & A & B & A & A & A & A & B & B & B & B \\
\hline 38. PEPD & B & C & A & B & D & B & B & A & A & A & A & $\mathbf{A}$ \\
\hline 39. PGAMA & A & A & A & A & A & A & A & $\mathbf{A}$ & A & A & A & A \\
\hline 40. PGD & $\mathrm{A} / \mathrm{B}$ & A & A & A & A & A & A & A & C & A & A & A \\
\hline 41. PGM1 & B & A & A & A & A & $A / B$ & A & A & A/B & A & A & A \\
\hline 42. PGM2 & - & $\mathrm{A}$ & A & B & A & A & $\mathrm{C}$ & A & C & B & A & A \\
\hline 43. PGM3 & B & - & - & A & - & A & A & A & A & - & - & A \\
\hline 44. PKM1 & A & A & A & A & A & A & A & A & A & A & $\mathbf{A}$ & A \\
\hline 45. PKM2 & B & A & A & A & A & A & A & A & B & C & $\mathrm{D}$ & D \\
\hline 46. PP & B & $\mathrm{A}$ & A & A & A & A & A & A & A & C & A & A \\
\hline 47. SOD1 & B & $\mathrm{A}$ & A & A & A & $\mathrm{B} / \mathrm{C}$ & B & A & A & A & A & A \\
\hline 48. TF & B & A & A & C & A & D & $\mathrm{D}$ & - & E & $\mathbf{F}$ & G & $\mathrm{H}$ \\
\hline 49. TPI & A & A & A & A & A & A & A & A & A & A & A & A \\
\hline 50. ALB & B & A & A & A & A & A & A & - & A & A & C & C \\
\hline 51. $\mathrm{HB}$ & B & $\mathrm{A}$ & A & $\mathrm{A}$ & - & A & - & A & C & A & C & A \\
\hline
\end{tabular}


APPENDIX 2. Continued.

\begin{tabular}{|c|c|c|c|c|c|c|c|c|c|c|}
\hline \multicolumn{11}{|c|}{ Group 2} \\
\hline $\mathrm{Cfa}$ & $\mathrm{Clu}$ & Cla & Cme & Lpi & $\mathrm{Cbr}$ & Fze & Ala & Vch & Vma & Vvu \\
\hline A & A & A & A & A & A & A & A & A & A & A \\
\hline A & B & C & A & C & A & A & A & A & A & A \\
\hline A & A & A & - & A & A & B & B & B & B & B \\
\hline A & A & A & A & A & A & A & A & A & A & A \\
\hline A & A & A & A & A & A & A & C & A & A & A \\
\hline- & - & - & - & - & - & - & - & - & - & - \\
\hline A & A & A & A & A/B & A & A & A & A & A & A \\
\hline A & A & A & A & A & A & A & A & A & A & A \\
\hline - & - & - & - & - & - & - & - & - & - & - \\
\hline A & A & A & A & A & A & A & A & A & A & A \\
\hline A & A & A & A & A & - & $\mathrm{A} / \mathrm{C}$ & A & $\mathrm{A} / \mathrm{C}$ & C & A \\
\hline A & A & A & - & A & A & A & A & - & A & A \\
\hline A & A & A & A & $\mathbf{A}$ & A & A & A & A & A & A \\
\hline A & A & A & A & A & B & C & $\mathrm{A} / \mathrm{D}$ & C & A/D & C \\
\hline- & - & - & - & - & - & - & - & - & - & - \\
\hline A & A & A & A & - & A & B & B & - & B & B \\
\hline A/B & A & A & A & A & C & C & C & C & C & A \\
\hline A & A & A & A & A & - & $\mathrm{A} / \mathrm{B}$ & A & - & - & B \\
\hline A & A & B & A & B & $\mathrm{B} / \mathrm{C}$ & B & B & B & A/B & B \\
\hline A & A & A & A & A & C & A & A & A & A & A \\
\hline A & A & A & A & A & - & - & A & - & B & A \\
\hline A & A & A & A & A & B & A & A & A & A & A \\
\hline A & A & A & - & A & A & B & - & C & C & C \\
\hline A & A & A & B & A & A & A & A & - & A & A \\
\hline- & - & - & - & - & - & - & - & - & - & - \\
\hline A & A & A & - & - & A & - & A & - & A & A \\
\hline A & A & A & A & A & A & A & A & B & A & A \\
\hline A & A & - & - & - & A & A & B & - & B & A \\
\hline A & A & A & A & A & A & A & A & A & A & $\mathbf{A}$ \\
\hline A & A & A & A & A & A & B & B & B & B & B \\
\hline A & A & A & B & A & A & A & $\mathrm{A} / \mathrm{B}$ & A/B & $\mathbf{A}$ & A/B \\
\hline A & A & A & - & A & A & B & - & - & B & B \\
\hline A & A & A & - & A & A & B & - & - & B & B \\
\hline $\mathrm{A} / \mathrm{B}$ & $\mathrm{A} / \mathrm{B}$ & B & - & - & C & C & $B / D$ & D & B & $C / D$ \\
\hline A & A & A & A & B & A & A & A & $\mathbf{A}$ & A & A \\
\hline A & A & A & A & $\mathbf{A}$ & B & A & A & C & A & A \\
\hline A & A & A & B & A & C & A & A & $\mathrm{A} / \mathrm{C}$ & A & A \\
\hline A & A & A & A & A & - & A & B & A & $\mathbf{A} / \mathbf{B}$ & A/B \\
\hline A & A & A & A & A & A & A & A & A & A & A \\
\hline A & A & A & A & A & A & A & A & $\mathbf{A}$ & A & A \\
\hline A & $\mathrm{A} / \mathrm{B}$ & A/B & C & A & $\mathbf{A}$ & A & A & A & A & A \\
\hline- & - & - & - & - & - & - & - & - & - & - \\
\hline- & A & A & - & - & B & B & - & - & B & B \\
\hline A & A & A & A & - & A & A & - & - & A & A \\
\hline A & A & A & A & B & A & B & B & B & B & B \\
\hline A & A & A & B & A & $\mathbf{A}$ & A & A & C & A & A \\
\hline A & A & A & A & $\mathbf{A}$ & A & A & A & A & A & A \\
\hline A & $\mathbf{A}$ & A & B & C & D & E & $\mathrm{D} / \mathrm{F}$ & G & $F$ & $\mathbf{H}$ \\
\hline A & A & A & A & $\mathbf{A}$ & $\mathbf{A}$ & $\mathbf{A}$ & A & A & $\mathbf{A}$ & $\mathbf{A}$ \\
\hline- & - & - & - & - & - & - & - & - & - & - \\
\hline A & A & A & A & A & A & A & A & A & A & A \\
\hline
\end{tabular}

